\title{
Technical note: Late Pliocene age control and composite depths at ODP Site 982, revisited
}

\author{
N. Khélifi ${ }^{1,}$, M. Sarnthein ${ }^{1}$, and B. D. A. Naafs ${ }^{2,3}$ \\ ${ }^{1}$ Institute of Geosciences, University of Kiel, 24118 Kiel, Germany \\ ${ }^{2}$ Alfred Wegener Institute for Polar and Marine Research, 27568 Bremerhaven, Germany \\ ${ }^{3}$ Leibniz Center for Earth Surface and Climate Studies, Institute for Geosciences Potsdam University, \\ 14476 Potsdam, Germany \\ * present address: Helmholtz Centre for Ocean Research Kiel (GEOMAR), 24148 Kiel, Germany
}

Correspondence to: N. Khélifi (nkhelifi@geomar.de)

Received: 8 March 2011 - Published in Clim. Past Discuss.: 24 May 2011

Revised: 21 October 2011 - Accepted: 25 November 2011 - Published: 6 January 2012

\begin{abstract}
Ocean Drilling Program (ODP) Site 982 provided a key sediment section at Rockall Plateau for reconstructing northeast Atlantic paleoceanography and monitoring benthic $\delta^{18} \mathrm{O}$ stratigraphy over the late Pliocene to Quaternary onset of major Northern Hemisphere glaciation. A renewed holespecific inspection of magnetostratigraphic reversals and the addition of epibenthic $\delta^{18} \mathrm{O}$ records for short Pliocene sections in holes $982 \mathrm{~A}, \mathrm{~B}$, and $\mathrm{C}$, crossing core breaks in the $\delta^{18} \mathrm{O}$ record published for Hole 982B, now imply a major revision of composite core depths. After tuning to the orbitally tuned reference record LR04, the new composite $\delta^{18} \mathrm{O}$ record results in a hiatus, where the Kaena magnetic subchron might have been lost, and in a significant age reduction for all proxy records by 130 to 20 ky over the time span 3.2-2.7 million years ago (Ma). Our study demonstrates the general significance of reliable composite-depth scales and $\delta^{18} \mathrm{O}$ stratigraphies in ODP sediment records for generating ocean-wide correlations in paleoceanography. The new concept of age control makes the late Pliocene trends in SST (sea surface temperature) and atmospheric $p \mathrm{CO}_{2}$ at Site 982 more consistent with various paleoclimate trends published from elsewhere in the North Atlantic.
\end{abstract}

\section{Introduction}

Several studies used the Pliocene sediment section of Ocean Drilling Program (ODP) Site 982 (Rockall Plateau; 57 $3^{\prime} \mathrm{N}$, $15^{\circ} 5^{\prime} \mathrm{W} ; 1134 \mathrm{~m}$ water depth) in the North Atlantic for paleoceanographic reconstructions. In particular, Lisiecki and Raymo (2005) used the $\delta^{18} \mathrm{O}$ record of Hole 982B on (old) composite depth as basis to establish the LR04 stacked record, Lawrence et al. (2009) for generating a record of Pliocene sea surface temperature (SST) oscillations, and Pagani et al. (2010) for reconstructing the late Pliocene $p \mathrm{CO}_{2}$ drop.

The Leg 162 Shipboard Scientific Party (1996) first established an age control at Site 982 for the upper Pliocene $(\sim 3.65-2.60 \mathrm{Ma})$ by means of both magnetic reversals in Hole A (with regard to the Matuyama-Gauss boundary; Channell and Lehmann, 1999; Channell and Guyodo, 2004) and an epibenthic $\delta^{18} \mathrm{O}$ record mostly obtained from Hole B (Venz and Hodell, 2002).

In our study, we supplemented the epibenthic $\delta^{18} \mathrm{O}$ record of Hole 982B and added intervals of records from holes 982A and $\mathrm{C}$ in order to bridge more accurately various coring gaps (Table S1; see Supplement). Using this approach we identified and had to insert small additional core sections previously overlooked by the Shipboard Scientific Party (1996) in the composite depth scheme. Consequently, we had to revise the late Pliocene chronostratigraphy at Site 982 and likewise, the trends of SST and $p \mathrm{CO}_{2}$, previously published. 


\section{Methods}

For the present study we took 345 additional sediment samples from holes 982A, B, and C (Table S1; see Supplement). The samples were weighed, oven-dried at $40^{\circ} \mathrm{C}$, weighed again (to obtain dry bulk density), and washed over a 63$\mu \mathrm{m}$ mesh-size sieve. The residue was dried at $40^{\circ} \mathrm{C}$ and finally sieved into 5 size fractions. Cibicidoides wuellerstorfi and $C$. mundulus were picked from the $>250-\mu \mathrm{m}$ fraction and analyzed for stable isotopes on a Finnigan MAT251 system, with a precision of $\pm 0.07 \%$ o for $\delta^{18} \mathrm{O}$ and $\pm 0.05 \%$ o for $\delta^{13} \mathrm{C}$, at the Leibniz Laboratory in Kiel. $\delta^{18} \mathrm{O}$ values of Cibicidoides spp. were corrected by $0.64 \%$ (Ganssen, 1983) (Table S1; see Supplement) to normalize them to $\delta^{18} \mathrm{O}$ values of Uvigerina, which are in equilibrium with ambient seawater (Shackleton, 1974). Figure 1S (see Supplement) shows the newly acquired $\delta^{18} \mathrm{O}$ data versus (new) composite depth (c.d.).

To establish the orbital age control at Site 982, we used the Analyseries software of Paillard et al. (1996) to tune the new composite benthic $\delta^{18} \mathrm{O}$ records to the orbitally tuned reference record LR04 (Lisiecki and Raymo, 2005).

To further support the construction of a composite depthscale for Site 982, the SST record form Lawrence et al. (2009) was supplemented by determining the alkenone unsaturation index $\left(\mathrm{U}_{37}^{k^{\prime}}\right)$ in 41 samples from Hole A between 66.925 and 72.4 (new) m c.d. (Fig. 3; Table S3; see Supplement). For this purpose, a LECO Pegasus III GC/TOF-MS system was used, which has the advantage over the classical GC/FID methods in that it is more sensitive and reduces instrumental time (further details in Hefter, 2008 and Naafs et al., 2010). Following Lawrence et al. (2009), we converted $\mathrm{U}_{37}^{k^{\prime}}$ values into SST using the calibration of Prahl et al. (1988) based on laboratory cultures of the marine coccolithophorid Emiliania huxleyi.

\section{Composite depth record}

The original composite-depth scale at Site 982 was derived from sediment records of continuous multi sensor logging (GRAPE density, magnetic susceptibility, $p$ wave velocity) in the four holes $982 \mathrm{~A}-\mathrm{D}$, and moreover, from records of spectral color reflectance (Shipboard Scientific Party, 1996). However, below $54 \mathrm{~m}$ composite depth (m c.d.), color reflectance was only measured in holes A and B. Between 55 and 72 (old) $\mathrm{m}$ c.d., all core fits amongst holes A, B, and C are poorly established as they cannot rely on specific oscillations and structures in the color reflectance and magnetic susceptibility records, here dropping to background levels. Also, poor structures in the GRAPE record appear unsatisfactory for composing a composite depth model (see Shipboard Scientific Party, 1996; Fig. 2 in Chapter 4). Thus, most correlations between holes $\mathrm{A}, \mathrm{B}$, and $\mathrm{C}$ are hardly unique but speculative, in particular amongst cores $\mathrm{B} 5$ to $\mathrm{B} 8, \mathrm{~A} 6-\mathrm{A} 8$, and C7-C10. In contrast, the oscillations of overlapping benthic $\delta^{18} \mathrm{O}$ records of holes $982 \mathrm{~A}-\mathrm{C}$ show numerous marked and unique structures that form a robust basis for establishing a reliable continuous composite depth scale (Fig. 1).

\section{Magnetostratigraphy framework}

The magnetic polarity of the upper Gauss chronozone (2An) is well reflected at Site 982 by core sections with normal inclination (shipboard data of Channell and Lehmann, 1999; update of Channell and Guyodo, 2004). In Hole A it ends with a sharp change in magnetic polarity at 57.28 m c.d. (50.70 mbsf) (Fig. 1). This midpoint depth of the Matuyama/Gauss (M/G) boundary was by now employed by all authors since Venz and Hodell (2002) for age-calibrating marine isotope stage (MIS) 104 in the Hole- $\mathrm{B} \delta^{18} \mathrm{O}$ record, where they had bridged the core break B6-B7 by a short piece of $\delta^{18} \mathrm{O}$ record from Hole A (57.5-59.69 m c.d.). However, this position of the $\mathrm{M} / \mathrm{G}$ boundary at $57.28 \mathrm{~m}$ c.d. (dated at $\sim 2.608 \mathrm{Ma}$ in LR04) is different from that found by Channell and Lehman (1999) in Hole B, where the midpoint of the reversal occurs at $58.06 \mathrm{~m}$ c.d. $(\sim 52.55 \mathrm{mbsf}), \sim 0.8 \mathrm{~m}$ deeper. Channell and Guyodo (2004) updated their shipboard magnetic data using u-channel samples, unfortunately without measuring the lowermost $100 \mathrm{~cm}$ in Core B6 (lowermost sections 6 and 7), and concluded that the M/G boundary in Hole B is located at the same composite depth as in Hole A.

However, we now added a new $\delta^{18} \mathrm{O}$ data set to bridge better the Core B6/B7 gap (Fig. S1; Supplement). These data revealed a clear record of MIS 104-G2 for the crucial section in Core B6 uncovered by u-channel data and for the top of Core B7, between 57.51 and $59.67 \mathrm{~m}$ c.d. (Fig. 1; Table S1, see Supplement). To link properly the evidence from these newly identified marine isotope stages with the magnetic record, we thus needed to stick to the records of shipboard single-step magnetic data of lowermost Core B6. Table 1 presents a comparative evaluation of the different qualities of the M/G boundary in the shipboard magnetic records of holes A, B, and C. Accordingly, the inclination boundary is best recorded in Core B6, near the top of section 7 .

In summary, we now took care of the discrepancy between the inclination records of holes A and B by means of a new $\delta^{18} \mathrm{O}$ stratigraphy, which requires a match of the lower MIS 104 with the M/G boundary - unfortunately in Core 6B only recorded in the shipboard magnetic data. Also, we are aware of several subsequent short-term oscillations toward less negative magnetic polarity that occur further upcore, up to $54.81 \mathrm{~m}$ c.d. We now lump these insignificant oscillations with the Matuyama chron (Fig. 1), in part following the uchannel record of Channell and Guyodo (2004). 


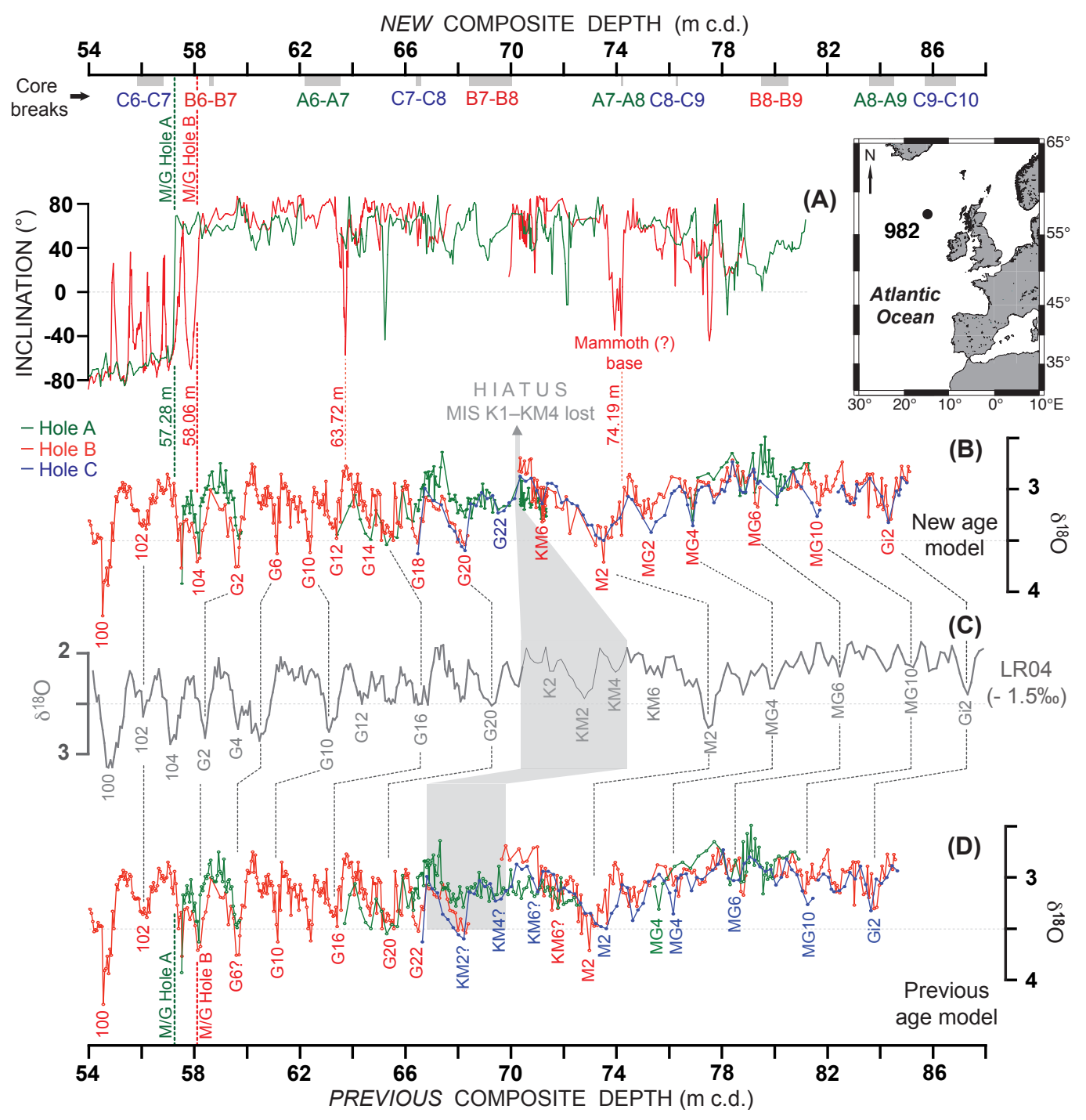

Fig. 1. Different models of age control for ODP Site 982 (location shown at inserted map). (A) Magnetic polarity reversals are from the shipboard inclination data for holes A (green) and B (red) (Channell and Lehman, 1999; Channell and Guyodo, 2004), plotted on new composite depth (c.d.) scale. $\mathrm{M} / \mathrm{G}=$ Matuyama/Gauss. (B) Benthic $\delta^{18} \mathrm{O}$ records of holes $982 \mathrm{~A}, \mathrm{~B}$, and C, plotted over the new c.d. scale (data of Venz and Hodell, 2002; suppl. by Lisiecki and Raymo, 2005, and by this study, as specified in Table S1; see Supplement; Fig. S1). Labeled isotope stages are tuned (hatched lines) to (C) benthic $\delta^{18} \mathrm{O}$ stack LR04 (Lisiecki and Raymo, 2005). (D) Benthic $\delta^{18} \mathrm{O}$ records of holes 982A, B, and C plotted over the "previous age model" of the Shipboard Scientific Party (1996), as cited by Lawrence et al. (2009). Small grey bars near the top depth scale mark potential losses of sediment sections at core breaks, which differ on the old and new composite depth scales below $68.36 \mathrm{~m}$ c.d. The two different c.d. scales for the $\delta^{18} \mathrm{O}$ records in holes $\mathrm{A}, \mathrm{B}$, and $\mathrm{C}$ lead to major age discrepancies at 58-72 (new) m c.d. Major grey bar near $70 \mathrm{~m}$ (new) c.d. constrains the stratigraphic interval in LR04, which is lost in a hiatus as a result of the new age model.

\section{Stable isotope stratigraphy and composite depths}

The initial $\delta^{18} \mathrm{O}$ record from Site 982 of Venz and Hodell (2002), which forms the backbone of Pliocene stratigraphy, was slightly supplemented by Lisiecki and Raymo (2005). These authors already identified a short hiatus between 2.25 and 2.33 Ma that removed MIS 86, 87, and 88. This gap is important in demonstrating that pelagic sedimentation at Site 982 was occasionally discontinuous.
The glacial-to-interglacial $\delta^{18} \mathrm{O}$ oscillations of our new benthic $\delta^{18} \mathrm{O}$ records now produce a series of new splice tie points between holes $982 \mathrm{~A}, \mathrm{~B}$, and $\mathrm{C}$. These points suggest a revision of the former splice of Hole-A, Hole-B, and Hole-C core sections at 63.68- 85.00 (new) m c.d. (Fig. 1b) (Table S2; see Supplement) as defined by the Shipboard Scientific Party (1996) (Fig. 1d). Our new tie points also modify the chronostratigraphic scheme proposed by Venz and Hodell (2002), which was tuned and incorporated into LR04 
Table 1. Evaluation of uncertainties in the midpoint assignment for definition of the Matuyama/Gauss (M/G) boundary in ODP holes 982 A, B, and C (inclination data of Channell and Lehmann, 1999).

\begin{tabular}{llll}
\hline & Potential artifacts & $\begin{array}{l}\text { Character of M/G Inclination } \\
\text { boundary }\end{array}$ & Conclusion \\
\hline Hole A & $\begin{array}{l}\text { Section break (no necessary } \\
\text { loss of record) }\end{array}$ & $\begin{array}{l}\text { Abrupt inclination reversal between } \\
\text { two fully opposed inclination data }\end{array}$ & $\begin{array}{l}\text { Lack of transition in the reversal suggests ar- } \\
\text { tifact (missing the impact of the bioturbational } \\
\text { mixing depth; Channell and Guyodo, 2004) }\end{array}$ \\
\hline Hole B & $\begin{array}{l}\text { Section break (no necessary } \\
\text { loss of record) }\end{array}$ & $\begin{array}{l}\text { 20-cm slope of inclination reversal } \\
\text { comprising a suite of six successive } \\
\text { data }\end{array}$ & $\begin{array}{l}\text { Optimum resolution of M/G boundary shows } \\
\text { gradual (bioturbated) transition in the } \\
\text { inclination signal }\end{array}$ \\
\hline Hole C & $\begin{array}{l}\text { Core break (potential } \\
\text { "oblition" of magnetic record) }\end{array}$ & $\begin{array}{l}\text { Abrupt inclination reversal between } \\
\text { two fully opposed inclination data }\end{array}$ & $\begin{array}{l}\text { Position of M/G boundary is affected by core } \\
\text { break }\end{array}$ \\
\hline
\end{tabular}

by Lisiecki and Raymo (2005). Admittedly, also the new core splice displays some minor, as yet unexplained, deviations in core fit. For example, at $66.37-68.36 \mathrm{~m}$ c.d. (MIS G19-20), the absolute $\delta^{18} \mathrm{O}$ levels in holes $\mathrm{B}$ and $\mathrm{C}$ are up to $>0.3 \%$ higher than in Hole A. On the other hand, the $\delta^{18} \mathrm{O}$ level in Hole $\mathrm{B}$ is up to $0.3 \%$ lower than in holes $\mathrm{A}$ and $\mathrm{C}$ at $\sim 70.31-70.76$ (new) m c.d. (MIS KM5). In general, however, the intercore deviations of $\delta^{18} \mathrm{O}$ excursions remain within the range of analytical uncertainty $( \pm 0.07 \%$; Fig. 1b).

Below $68.36 \mathrm{~m}$ c.d., the new splice of composite depths requires an additional downhole shift of the core top $\mathrm{B} 8$ by $\sim 0.5 \mathrm{~m}$. By comparison with holes A and C, core break B7B8 now covers a gap of $\sim 2 \mathrm{~m}$, from 68.36 to at least $\sim 70.31$ (new) $\mathrm{m}$ c.d., whereas core break B8-B9 has lost a section between $\sim 79.4$ and 80.5 (new) m c.d. (Figs. 1b vs. 1d).

\section{Discussion of correlations in stable-isotope stratigraphy}

At Site 982, the published definitions of late Pliocene MIS mostly relied on the largely continuous benthic $\delta^{18} \mathrm{O}$ record of Hole B. Short $\delta^{18} \mathrm{O}$ records were measured in Hole A for bridging core breaks B6-B7, B7-B8, and B8-B9 (Venz and Hodell, 2002; supplemented by Lisiecki and Raymo, 2005). We now prolonged the $\delta^{18} \mathrm{O}$ master record of Hole $\mathrm{B}$ for short sections at the base of core B6 and top of B7 between 57.51 and $59.67 \mathrm{~m}$ c.d. and replaced the M/G boundary in Hole A at $50.70 \mathrm{mbsf}$ ( $57.28 \mathrm{~m}$ c.d.) by that in Hole B at $52.55 \mathrm{mbsf}$ ( $58.06 \mathrm{~m}$ c.d.) to be consistent with age calibrating MIS 104 now defined in Hole B.

The new tuning is superior to the old stratigraphic record in particular at two depth sections: (1) at 57-62 m c.d. and (2) at 66-72 (new) $\mathrm{m}$ c.d. Figure 2 shows the resulting new suite of benthic $\delta^{18} \mathrm{O}$ oscillations in holes $\mathrm{A}, \mathrm{B}$, and $\mathrm{C}$, re-adjusted to the orbitally tuned reference record LR04. Accordingly, the composite depth position of the M/G boundary shifted
$0.78 \mathrm{~m}$ downcore (Table 1 ). This shift also implied a redefinition of the nomenclature of several preceding marine isotope stages as outlined below.

Different from LR04, the part of the $\delta^{18} \mathrm{O}$ record that now corresponds to MIS 104 appears bipartite at Site 982, with a second, very short cold excursion in the upper part, a structure likewise found in the $\delta^{18} \mathrm{O}$ records of holes A and B. A similar bipartite benthic MIS 104 is also found at nearby Site 548 at similar water depths in the northeast Atlantic (Khélifi et al., 2009), demonstrating that this feature is not unique to Site 982 . Subsequent to MIS 104, the suite of MIS 103-100 closely reflects all details of amplitude and structure as defined in LR04 and reported in previous studies.

In addition, all stages of the suite G1 to G10 prior to MIS 104 (redefined at Hole-B depth of $58.06 \mathrm{~m}$ c.d.) now resemble in detail the structures and amplitudes displayed in LR04, when using our new stratigraphic nomenclature. Perhaps, the $\delta^{18} \mathrm{O}$ excursion at glacial MIS G4 is a little less pronounced than the coeval signal in LR04 (Fig. 2). However, once more it is analogous to the $\delta^{18} \mathrm{O}$ record at Site 548 (Khélifi et al., 2009). In particular, the amplitude of G10 now clearly exceeds that of all preceding "cold" MIS, as suggested by LR04, and thus strongly differs from the previous tuned version (Lisiecki and Raymo, 2005). Further back, from MIS G11 ( $\sim 2.83 \mathrm{Ma})$ back to G20 $(\sim 3.01 \mathrm{Ma})$, the redefined MIS oscillations such as MIS G13 and the bipartite MIS G15 likewise resemble closely those of LR04.

In contrast to the outlined general match of MIS structures, the amplitude of MIS G13 appears clearly more negative in $\delta^{18} \mathrm{O}$ in Hole B than in Hole A and LR04. In contrast to LR04, the high amplitude of MIS G13 exceeds that of bipartite MIS G17. However, G13-G17 show a similar suite of amplitudes in ODP Site 846 (Tiedemann et al., 1994). MIS G13 coincides with a very short, marked interval of questionable negative inclination within the Gauss Chron near $63.72 \mathrm{~m}$ c.d. in Hole B (depicted in Fig. 1a, b despite of low magnetization intensities; Chanell and Lehman, 1999). The 


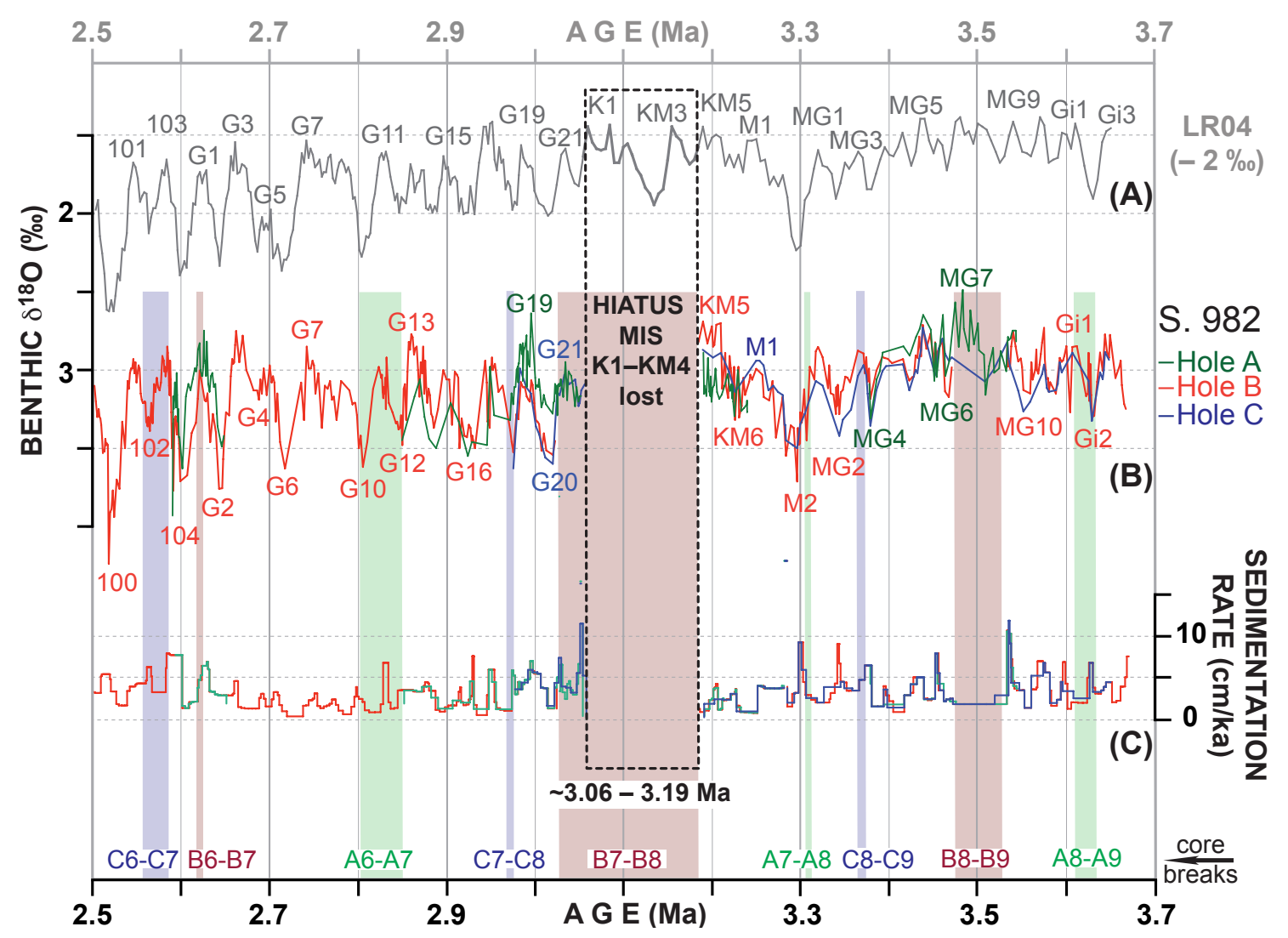

Fig. 2. (B) New marine-isotope stage chronology for $\delta^{18} \mathrm{O}$ records of ODP holes 982A, B, and C versus age (data from Venz and Hodell, 2002, Lisiecki and Raymo, 2005, and this study, as specified in Table S1) vs. (A) $\delta^{18}$ O record of global ice volume LR04 (Lisiecki and Raymo, 2005) and (C) sedimentation rate changes.

"excursion" cannot be correlated to the theoretically nearby Kaena event, and thus is discarded. Further downcore, the amplitudes of MIS G19 in holes B and C are as high as suggested by LR04, which is lower than the amplitude of G17. In contrast, the relative amplitude of MIS 19 in Hole A clearly exceeds that of LR04. The broad and marked positive $\delta^{18} \mathrm{O}$ excursion of MIS 20 in holes B and $\mathrm{C}$ is somewhat more distinct and thus comes much closer to that suggested by LR04 than the weak G20 excursion found in Hole A (Fig. 2). We do not understand yet the more negative $\delta^{18} \mathrm{O}$ levels in the Hole-A record, although the relative amplitudes of the $\delta^{18} \mathrm{O}$ excursions for $\mathrm{G} 20$ are largely the same in all three holes.

The second critical depth section leading to new stratigraphic insights occurs prior to MIS G20, an interval that is particularly important for paleoceanography, since it is matching the PRISM time slice (Dowsett et al., 2010) for late Pliocene climate reconstruction, where Site 982 is forming a northeast Atlantic "cornerstone". The newly defined MIS G20 occurs at the lower end of the $\delta^{18} \mathrm{O}$ record in core B7; the relative amplitudes of preceding MIS G21 and G22 in the (new) hole- $\mathrm{A}$ and $\mathrm{C}$ records now match closely the pertinent features in LR04. However, the two hole-A and C records do not extend beyond the base of MIS G22 and do not reach back to the $\delta^{18} \mathrm{O}$ spike at the top of core B8, which probably occurs right at the end of KM5. Thus, the joint $\delta^{18} \mathrm{O}$ record of the continuous sediment sections in holes $\mathrm{A}$ and $\mathrm{C}$ do not bridge completely the (now expanded) coring gap at core break B7-B8 between 68.36 and $\sim 70.31$ (new) m c.d. (Figs. 1b, 2).

A correlation with LR04 suggests that the newly defined data-devoid interval from top K1 back to KM4 is interpreted as major stratigraphic hiatus, per analogy with the gap found for MIS 86, 87, and 88 (Venz and Hodell, 2002). Because of picture quality, we were unable to identify the gap on core photographs for holes A and C. The loss of MIS K1-K2 and KM1-KM4 necessarily would also imply a complete loss of the magnetic signals that traced the coeval Kaena magnetic subchron (poorly documented anyway because of low magnetization intensities). We are aware that these shifts still leave unsolved a discrepancy between the $\delta^{18} \mathrm{O}$ record of Hole A and the parallel records of holes B and C at stage KM5, possibly a result of small-scale differences in local sediment loss. Various lines of evidence that lead to our assumption of a major hiatus preceding MIS G22 are summarized in Table 2. 
Table 2. Lines of evidence that justify the hiatus between MIS G22 and KM5.

Consecutive rejuvenation of stable-isotope stratigraphy prior to MIS 104 as induced by the replacement of marine isotope stages G5-G9 by G1-G4, which in turn resulted from the substitution of the M/G boundary in Hole A by that in Hole B (Table 1) to match directly the $\delta^{18} \mathrm{O}$ master record of Hole B. This shift sums up to more than $80 \mathrm{ky}$.

Our supplementary $\delta^{18} \mathrm{O}$ records (Fig. S1; see Supplement) of holes $982 \mathrm{~A}$ and $\mathrm{C}$ measured to fill the B7/B8 coring gap, revealed the structures of MIS stages G21 and G22 in addition to the $\delta^{18} \mathrm{O}$ oscillations previously displayed in the stableisotope stratigraphy of Venz et al. (2002). These additional stages sum up to more than $40 \mathrm{ky}$.

As compared to the previous age model (Lawrence et al., 2009) the similarity of $\delta^{18} \mathbf{O}$ variations with the reference record LR04 appears much improved between MIS G1 and G12, for G14-G16, and G20-G22, hence requiring a continuous sediment record back to the base of MIS G22 and excluding a potential stratigraphic gap further upcore, say, between G1 and G4 (Lawrence, personal communication, 2011).

On the basis of the now completed $\delta^{18} \mathrm{O}$ records for holes $982 \mathrm{~A}-\mathrm{C}$ (Fig. S1) the composite depths were newly defined between 66 and 85 (old) $\mathrm{m}$ c.d. Within this depth range the unequivocal fit of records between 72 and 85 (old) $\mathrm{m}$ c.d. and various comparative tests (not depicted) suggest an optimum fit of the three $\delta^{18} \mathrm{O}$ records as depicted in Fig. 1. Accordingly, the $\delta^{18} \mathrm{O}$ records of holes $\mathrm{A}$ and $\mathrm{C}$ are incapable to fill the total coring gap between $\mathrm{B} 7$ and $\mathrm{B} 8$ and require a stratigraphic gap for MIS K1-KM4.

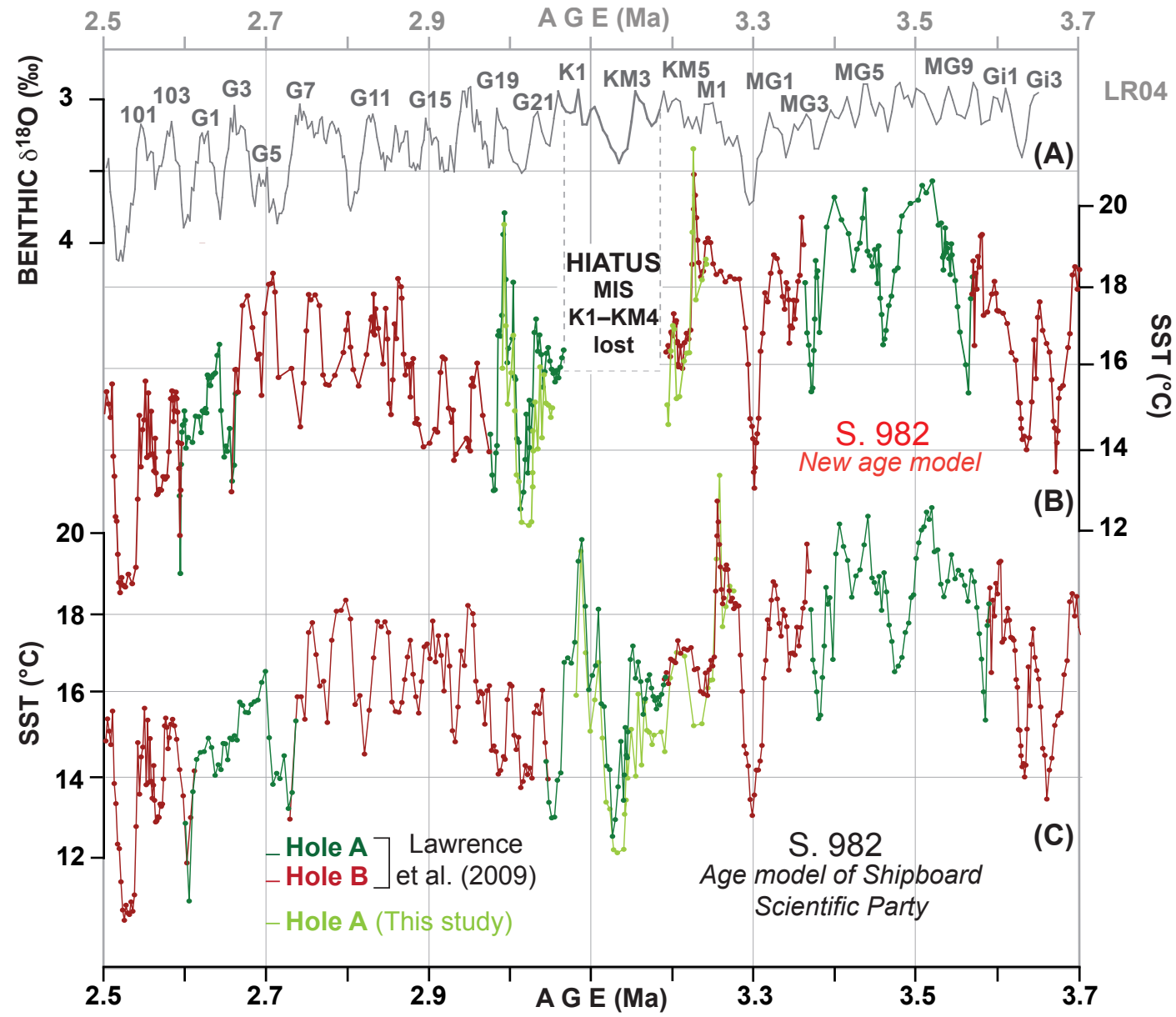

Fig. 3. $\mathrm{U}_{37}^{k^{\prime}}$-based SST records of ODP holes 982A (green) and B (red) (Lawrence et al., 2009) plus new $\mathrm{U}_{37}^{k^{\prime}}$ data of Hole A (light green) (suppl. by this study), plotted both on the new (B) and previous (C) age scales and versus (A) the $\delta^{18} \mathrm{O}$ global ice volume record LR04 (Lisiecki and Raymo, 2005). 


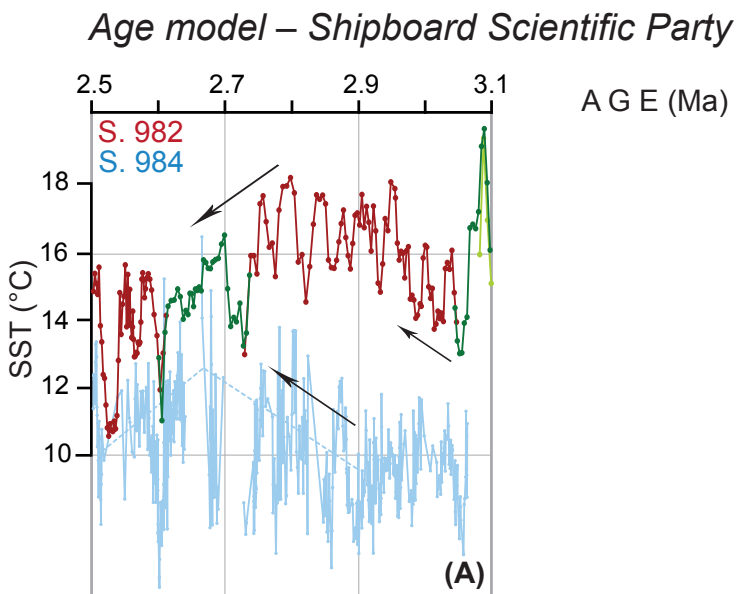

\section{New age model}
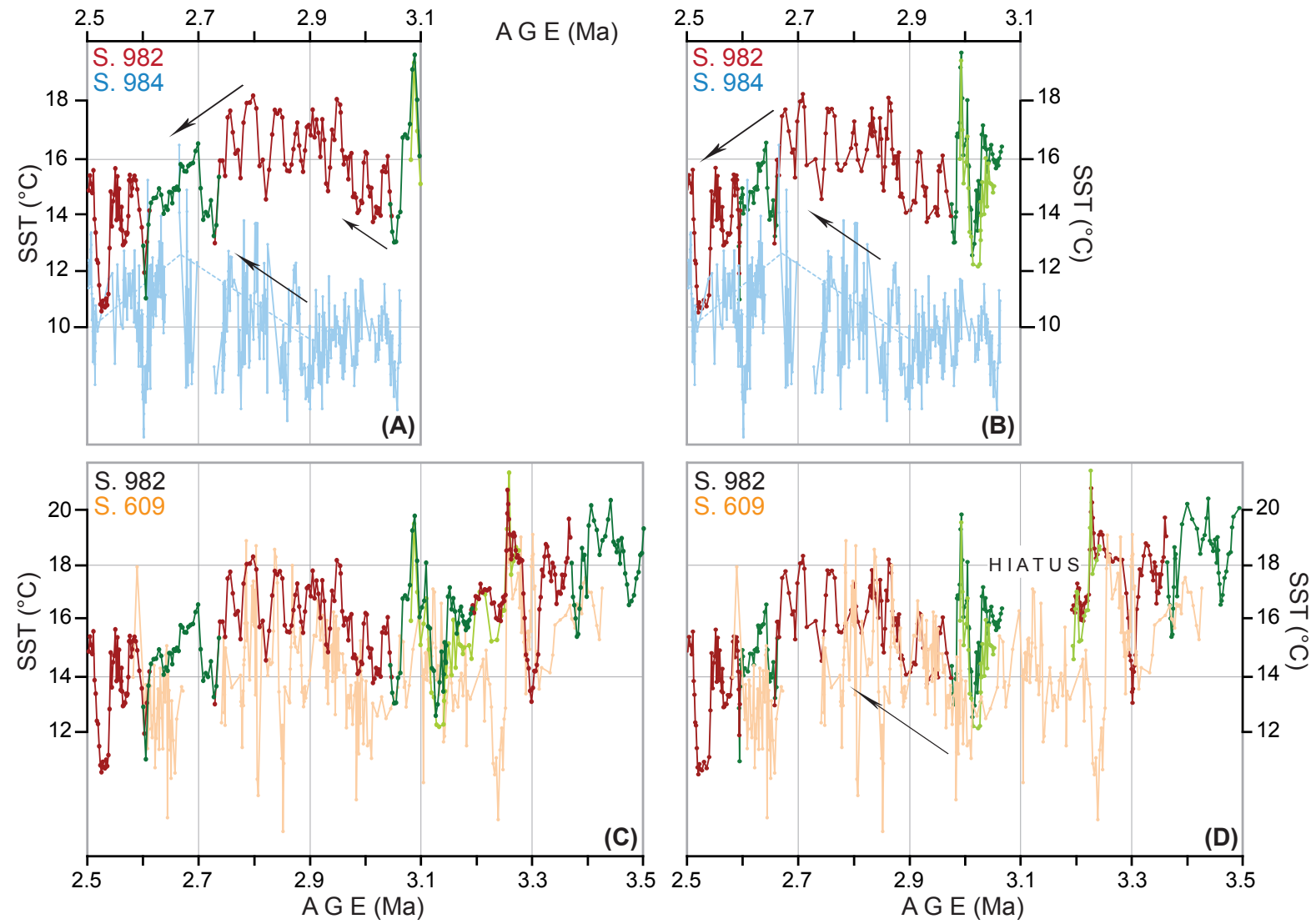

Fig. 4. Comparison of $\mathrm{U}_{37}^{k^{\prime}}$-based SST records of ODP holes $982 \mathrm{~A}$ (green and light green) and B (red) (for details see caption of Fig. 3) with $\mathrm{Mg} / \mathrm{Ca}$-based SST records analyzed at ODP sites 984 and 609 (Bartoli et al., 2005), plotted both versus the old and new age models discussed in this study.

Prior to KM5, the records of holes A and $\mathrm{C}$ require only minor shifts in composite depth near MG2-MG5 to adjust them closely to the MIS record of Hole B (Table S2; see Supplement). The stage chronology of Hole B is retained unchanged back to MIS Gi2 such as previously tuned to LR04 by Lisiecki and Raymo (2005).

Near 74.19 (new) m c.d., the onset of a significant positive excursion in $\delta^{18} \mathrm{O}$ marks the onset of the extremely cold MIS M2, which can be aligned with a well-resolved broad "event" of negative inclination within the Gauss Chron (Channell and Lehmann, 1999) (Fig. 1a), a coincidence that appears to occur beyond coincidence. Accordingly, we may now consider this magnetic excursion as part of the Mammoth subchron at $\sim 3.3 \mathrm{Ma}$ (Lisiecki and Raymo, 2005). The upper part of this subchron was probably lost. Unfortunately, the low magnetization intensities do not allow an identification of the Gauss/Gilbert boundary.

\section{Implications}

Our new stratigraphic correlations imply a revised chronology for the $\mathrm{U}_{37}^{k^{\prime}}$-based SST record of Site 982, which covers the late Pliocene onset of major northern Hemisphere glaciation (Lawrence et al., 2009). Subsequent to 3.2 Ma, we now have to reduce the ages of SST signals by values that vary between more than 130 and $20 \mathrm{ky}$, because the age of a $\delta^{18} \mathrm{O}$ signal formerly assigned to MIS KM4 $(\sim 3.175 \mathrm{Ma})$ is now replaced by the age of MIS G22 ( 3.045 Ma) (Fig. 3).

Accordingly, we see three late Pliocene main cooling events of northeast Atlantic SST, which Lawrence et al. (2009) constrained to $\sim 4.5^{\circ} \mathrm{C}$ each. These events are clearly supported and/or rendered more prominent by our new $\mathrm{U}_{37}^{k^{\prime}}$ data such as at MIS G20. A first but short-term reversible cooling was linked to MIS M2. In contrast to the conclusions of Lawrence et al. (2009), the first major long-term cooling occurred on the basis of the new age scale only somewhere between $\sim 3.24$ and $3.02 \mathrm{Ma}$, possibly only near the end of the hiatus. The second major cooling has shifted to $\sim 2.7-2.53 \mathrm{Ma}$. An intermediate phase of 
asymptotic warming by $3{ }^{\circ} \mathrm{C}$ lasted from $\sim 2.98$ until $2.7 \mathrm{Ma}$. On the basis of our revised chronology, these ages and many SST trends now compare better with coeval trends of SST changes found elsewhere in the northern North Atlantic, for example, at ODP Site 609 to the south of Site 982 and at Site 984 in the Irminger Current (Bartoli et al., 2005) (Fig. 4). In summary, it turns out that most of the northeastern North Atlantic did not cool down but gradually warmed up during the late Pliocene from $\sim 2.95$ to $2.7 \mathrm{Ma}$, a trend that was induced by the final closure of the Central American Seaways, in harmony with various model simulations (Lunt et al., 2007; Sarnthein et al., 2009).

Likewise, our new age model may have implications for other trends in paleoclimate such as the major late Pliocene reduction in atmospheric $\mathrm{CO}_{2}$. At Site 982, Pagani et al. (2010) placed a (poorly constrained) late Pliocene $\mathrm{CO}_{2}$ drop somewhere between $\sim 3.3$ and $2.85 \mathrm{Ma}$ (Fig. S3). On the basis of our new age model, the time span of $\mathrm{CO}_{2}$ reduction is now expanded by more than 80 ky until $\sim 2.75 \mathrm{Ma}$ (MIS G6). The latter timing appears to be in closer harmony than previously assumed with the onset of a major long-term decrease in bottom water temperatures at ODP Sites 609 and 610 in the North Atlantic, then tracing a significant rise in meridional overturning circulation and hence, an increased North Atlantic drawdown of atmospheric $\mathrm{CO}_{2}$ (Bartoli et al., 2005; Sarnthein et al., 2009). However, the highly fragmentary $\mathrm{CO}_{2}$ evidence of Site 982 (Fig. S3) does not provide yet any substantial insights into the actual details of leads and lags between the atmospheric $p \mathrm{CO}_{2}$ drop and the onset of major Northern Hemisphere glaciation during the late Pliocene.

\section{Conclusions}

In our study, we revised the age-calibration of the late Pliocene $\delta^{18} \mathrm{O}$ master record measured in Hole 982B. In contrast to previous schemes of age control (Venz and Hodell, 2002; Lisiecki and Raymo, 2005; Lawrence et al., 2009), we replaced - here without changing the composite-depth scale published by the Shipboard Scienific Party (1996) - the M/G boundary in Hole 982A by that in Hole 982B (Channell and Lehmann, 1999), which occurs $\sim 0.78 \mathrm{~m}$ farther downhole and corresponds directly to MIS 104 in the Hole-B $\delta^{18} \mathrm{O}$ record. Moreover, the $\delta^{18} \mathrm{O}$ record of Hole 982B near to the core break B6-B7 was prolonged farther up- and downcore. In total, these changes led to a reduction of sediment ages by up to $80 \mathrm{ky}$ and a significantly improved match of MIS G1-G12 structures with those found in the reference record LR04.

New $\delta^{18} \mathrm{O}$ records from holes $982 \mathrm{~A}$ and $\mathrm{C}$ between $\sim 64$ and 84 (new) $\mathrm{m}$ c.d. were measured in parallel to the master record of Hole B. These records and many additional data helped us to improve the sampling resolution of the Hole-B record and thus, on the definition of stage numbers around core breaks B7-B8 and B8-B9. Here, the optimum mu- tual overlap amongst all three $\delta^{18} \mathrm{O}$ records and their closestpossible match with MIS structures defined in LR04 also require a major revision of the composite-depth scale displayed in Table S2 (see Supplement). Most important, they suggest a natural hiatus of more than 130 ky between the base of MIS KM4 and the top of MIS K1. This gap corroborates the outlined age shift at MIS G22-G1. In contrast to the outlined age shifts, previous definitions of MIS KM5 back to Gi2 are confirmed. Here, it might be possible to identify the Mammoth magnetic subchron in Hole 982B at the base of MIS M2.

The large-scale age reduction subsequent to MIS KM5 implies a number of reasonable shifts in the tipping points and gradients of paleoclimatic signals, including North Atlantic SST trends and the atmospheric $p \mathrm{CO}_{2}$ drop, that mark the late Pliocene onset of major Northern Hemisphere glaciation.

\section{Supplementary material related to this article is available online at: http://www.clim-past.net/8/79/2012/ cp-8-79-2012-supplement.pdf.}

Acknowledgements. We thank Nils Anderson, Kiel, for stable isotope analyses. Hartmut Kühn and other students helped with careful sample preparation. We acknowledge constructive comments and questions of Kira Lawrence, Jim Channell, Martin Ziegler, Peter Bloxsom, and an anonymous CPD referee. This study was supported by the Deutsche Forschungsgemeinschaft (DFG) and the Deutscher Akademischer Austausch Dienst (DAAD).

Edited by: P. Ziveri

\section{References}

Bartoli, G., Sarnthein, M., Weinelt, M., Erlenkeuser, H., GarbeSchönberg, D., and Lea, D. W.: Final closure of Panama and the onset of northern hemisphere glaciation, Earth Planet. Sci. Lett., 237, 33-44, doi:10.1016/j.eps1.2005.06.020, 2005.

Channell, J. E. T. and Guyodo, Y.: The Matuyama Chronozone at ODP Site 982 (Rockall Bank): Evidence for decimeter-scale magnetization lock-in depths, in: Timescales of the Paleomagnetic Field, edited by: Channell, J. E. T., Kent, D. V., Lowrie, W., and Meert, J., Geoph. Monog. Series, 145, 205-219, 2004.

Channell, J. E. T. and Lehman, B.: Magnetic stratigraphy of North Atlantic Sites 980-984, in: Proceedings of Ocean Drilling Program Scientific Results, 162, edited by: Raymo, M. E., Jansen, E., Blum, P., and Herbert, T. D., College Station, Tx, 113-130, doi:10.2973/odp.proc.sr.162.002.1999, 1999.

Dowsett, H. J., Robinson, M., Haywood, A., Salzmann, U., Hill, D., Sohl, L., Chandler, M., Williams, M., Foley, K., and Stoll, D.: The PRISM3D paleoenvironmental reconstruction, Stratigraphy, 7, 123-139, 2010.

Ganssen, G.: Dokumentation von küstennahem Auftrieb anhand stabiler Isotope in rezenten Foraminiferen vor Nordwest-Afrika, "Meteor" Forschungsergeb., 37, 1-46, 1983. 
Hefter, J.: Analysis of Alkenone Unsaturation Indices with Fast Gas Chromatography/Time-of-Flight Mass Spectrometry, Anal. Chem., 80, 2161-2170, doi:10.1021/ac702194m, 2008.

Khélifi, N., Sarnthein, M., Andersen, N., Blanz, T., Frank, M., Garbe-Schönberg, D., Haley, B. A., Stumpf, R., and Weinelt, M.: A major and long-term Pliocene intensification of the Mediterranean Outflow, 3.5-3.3 Ma ago, Geology, 37, 811-814, doi:10.1130/G30058A.1, 2009.

Lawrence, K. T., Herbert, T. D., Brown, C. M., Raymo, M. E., and Haywood, A. M.: High amplitude variations in North Atlantic sea surface temperature during the early Pliocene warm period, Paleoceanography, 24, PA2218, doi:10.1029/2008PA001669, 2009.

Lisiecki, L. E. and Raymo, M. E.: A Pliocene-Pleistocene stack of 57 globally distributed benthic $\delta^{18} \mathrm{O}$ records, Paleoceanography, 20, PA1003, doi:10.1029/2004PA001071, 2005.

Lowrie, W. and Alvarez, W.: One hundred million years of geomagnetic polarity history, Geology, 9, 392-397, 1981.

Lunt, D. J., Valdes, P. J., Haywood, A. M., and Rutt, I. C.: Closure of the Panama Seaway during the Pliocene: implications for climate and Northern Hemisphere glaciation, Clim. Dynam., 30, 1-18, 2007.

Naafs, B. D. A., Stein, R., Hefter, J., Khélifi, N., De Schepper, S., and Haug, G. H.: Late Pliocene changes in the North Atlantic Current, Earth Planet. Sci. Lett., 298, 434-442, doi:10.1016/j.epsl.2010.08.023, 2010.

Pagani, M., Liu, Z., LaRiviere, J., and Ravelo, A. C.: High Earth-system climate sensitivity determined from Pliocene carbon dioxide concentrations, Nat. Geosci., 3, 27-30, doi:10.1038/ngeo724, 2010.
Paillard, D., Labeyrie, L., and Yiou, P.: Macintosh program performs time-series analysis, EOS Trans, AGU, 77, 379, doi:10.1029/96EO00259, 1996.

Prahl, F. G., Muehlhausen, L. A., and Zahnle, D. L.: Further evaluation of long-chain alkenones as indicators of paleoceanographic conditions, Geochim. Cosmochim. Ac., 52, 2303-2310, 1988.

Sarnthein, M., Bartoli, G., Prange, M., Schmittner, A., Schneider, B., Weinelt, M., Andersen, N., and Garbe-Schönberg, D.: Mid-Pliocene shifts in ocean overturning circulation and the onset of Quaternary-style climates, Clim. Past, 5, 269-283, doi:10.5194/cp-5-269-2009, 2009.

Shackleton, N. J.: Attainment of isotopic equilibrium between ocean water and the benthonic foraminifera genus Uvigerina: isotopic changes in the ocean during the last glacial, Colloques Internationaux du Centre National du Recherche Scientifique, 219, 203-210, 1974.

Shipboard Scientific Party: Site 982: in Proceedings of Ocean Drilling Program Initial Reports, 162, edited by: Raymo, M. E., Jansen, E., Blum, P., and Herbert, T. D., 91-138, 1996.

Tiedemann, R., Sarnthein, M., and Shackleton, N.: Astronomical timescale for Pliocene Atlantic $\delta^{18} \mathrm{O}$ and dust flux records of Ocean Drilling Program Site 659, Paleoceanography, 9, 619638, 1994.

Venz, K. A. and Hodell, D. A.: New evidence for changes in PlioPleistocene deep water circulation from Southern Ocean ODP Leg 177 Site 1090, Palaeogeogr. Palaeoecol., 182, 197-220, 2002. 